\title{
A brief history of salivary gland surgery
}

\section{Uma breve história da cirurgia das glândulas salivares}

Giulianno Molina Melo, TCBC-SP1; Onivaldo Cervantes; Marcio Abrahao'; Luciene Covolan²; Elenn Soares Ferreira²; Heloisa Allegro Baptista ${ }^{3}$.

\section{A B S T R A C T}

\begin{abstract}
Salivary gland neoplasms are a relatively uncommon disease, with nearly one case per 100.000 adults estimated per year and an overall incidence of $1 \%$ of all neoplasms. The benign neoplasms are majority and the prognosis depends on the histologic type, grade, localization, soft tissue infiltration, regional and distant metastasis. The main treatment is surgery with caution to facial nerve in the major salivary glands, followed by radiotherapy and chemotherapy in selected cases. The objective of this review is to provide the lector an historic approach about salivary gland diseases treatment, with special attention to the parotid neoplasms and its peculiarities associated to those who studied these glands in their history course.
\end{abstract}

Keywords: General Surgery. Parotid Gland. Parotid Neoplasms. History of Medicine

\section{INTRODUCTION}

Salivary glands neoplasms are relatively rare, corresponding to $1 \%$ of all tumors in the USA and $1 \%$ of head and neck tumors, affecting 1/100,000 persons per year, varying according to each studied country. Benign neoplasms predominate, but statistical data of the real incidence are rare. Prognosis depends on histologic type, differentiation grade, local (bigger salivary glands - parotid, submandibular - and smaller), infiltration of neighbor tissues and regional or distant metastasis.

Main benign histologic types are: pleomorphic adenoma, Warthin tumor, myoepithelioma, basal cells adenoma and oncocytoma. Among malignant tumors the most frequent are: cystic adenoid carcinoma, mucus-epidermoid, carcinoma ex-adenoma, acinic cell carcinoma, myoepithelial carcinoma, adenocarcinoma, basal cell carcinoma.

Median age of occurrence is 65 years, but it is continuously diminishing. Associated factors include smoking, alcohol abuse, radiation, hormones, occupational hazard, genetic predisposition and viral.

The main treatment is still surgery, which is challenging and difficult due to the presence of facial nerve branches in the bigger salivary glands, followed by radiotherapy, and, in selected patients, adjuvant chemotherapy.

Due to heterogeneity of cases, prognosis also varies, with survival of up to $91 \%$ in five years for initial cases, to $75 \%$ for patients with regional dissemination and $39 \%$ of patients with distant metastasis. Median is $72 \%$ in five years for most malignant tumors.

The objective of the present review is to provide the lector an historic approach on the treatment of salivary glands diseases, with special attention to parotid gland diseases and particularities of those who studied over the years those diseases. We hope to increase knowledge of historical data of these diseases, that are seldomly treated by general surgeons.

This paper was approved by the Ethical Committee and of Research of Federal University of São Paulo, \# 180495.

\section{Salivary Glands Along History}

In the known history of Medicine, the oldest reference of salivary glands and more specifically of saliva, was in old Mesopotamia, in clay tablets, in 2,500 BC, at Akka Library, created by the Syrian king Assurbanipal. The description refers to belladonna used as a useful medicine to stop the excessive flow

1 - Federal University of the State of São Paulo (UNIFESP), Department of Otolaryngology and Head and Neck Surgery, São Paulo, SP, Brazil. 2 - UNIFESP, Neurophysiology Laboratory of Physiology Department, SP, Brazil. 3 - UNIFESP, Center for the Development of Experimental Models - CEDEME, São Paulo, SP, Brazil. 
of saliva: "...If the saliva in a man's mouth does not cease to flow, that man has been bewitched: for [his] recovery, thou shalt bray together. . . eligulla, savin (or tragacanth), [he shall drink] in kurunnu-beer, [and he shall recover]" 1 .

In the old Egypt papyrus, saliva is mentioned related to speech, according to the scripts of Ghaliounghi², and there was no mention to diseases of salivary glands.

In old Greek Medicine, Hippocrates (460370 BC) studies, transcripted by Adams in 1849, refer to diseases of salivary glands such as suppurative and non-suppurative mumps, distinguishing them from epidemic mumps; they were characterized according to seasonality and were cited on the book I of "Epidemiae"3. The author, Aurelius Cornelius Celsus (25BC to $50 \mathrm{AC}$ ) described in his sixth book, at chapter 16, the parotid gland, and in his seventh book, the appearance of ranula ${ }^{4}$.

Paulus Aegineta (607-690 AC) refers to the parotid gland as a "gland close to the ears, that harbors infections sometimes caused by head humors that impact on them and sometimes by body collected humors after fever crises" 5 . Galeno de Pérgamo ${ }^{6}$ (129/130 - 200/216 AC) in his book about Nerve Dissection, refers to dissection of optic nerve and others until seventh pair, with ramifications and interconnections "qui inter se conjungantur", referring to salivary glands as "a sponge that would clean the blood, eliminating impurities".

Ancient Islamic Medicine also quotes salivary glands, presenting and adding citations by the renowned Hippocrates and Galeno. We can quote Rhazi (al-Razi 865-925 AC) that brilliantly described facial paralysis very similar to nowadays Bell's paralysis, Avicenna (IbnSina 980-1037 AC), that described in his third book from "Canon of Medicine" the finding of ranula under the tongue as a mass similar to a frog, and also described other oral cavity tumors, and Abulcasis ${ }^{9}$ (Al Zahrawi 936-1013 AC), that described in his encyclopedia "Al-Tasrif" the ranula, a structure similar to a frog: "it is a tumor similar to a frog generated by pure expectoration or by expectoration mixed with black material; its signal is a whitish color with moist expectoration and its dark mixed color is characterized as black, rigid and with low humidity".

After that, it follows a long dark period of Eastern medicine, with no or very few reports about salivary glands, probably due to a historical moment when very few had knowledge, that was restricted to monasteries protected by feudal lords, that were isolated fearing barbarian invasions.

Only in 16th Century, in the medieval medicine, again we find descriptions of salivary glands by anatomists, that followed the Greek school. It is important to highlight Ambroise Paré ${ }^{10}$ from France, that wrote in his sixth book "Traitant Des Tumeurs Contre Nature in Particulier" (Chapter III) about a tumor behind the ears, called parotid: «Parotide, est une tumeur contre nature, occupant les glandules et parties d'autour, qui sont sous le oreilles dites emonctoires du cerveau: lesquelles, parce qu'elles sont laxes et rares, facilement reçoivent les excremens d'iceluy», exposing the humor theory of origin of diseases, an Hippocratic and Galenic principle.

There is also a mention of salivation by the Old Chinese Medicine, in the period that correspond to antient age of China, described at the "Huang di nei jing su wen" and its production as a humor liquid, six centuries before Christ, comparing Ying and Yang theory to old Hippocratic school ${ }^{11}$.

\section{The First Anatomists: Medieval and Renascence Medicine}

Some scholars next presented contributed to the development of the knowledge about salivary glands, presenting, in a scientific and ordered manner (a common fact of that time), an anatomic detailed and documented study. We will present the most important and their respective discoveries.

The great anatomist and founder of modern human anatomy was Andreas Vesalius ${ }^{12}$ (15141564), that taught at Padova University and was a physician at Emperor Carlos V' court (of Italy and Germany). He described and recognized the salivary glands and gave them their correct importance in his Atlas "De Humani Corporis Fabrica Libre Septem" in 1543; he described at Book II, Table I, letter A, the submandibular gland. 
We can also quote Bartolomeu Eustachii ${ }^{13}$ (1500-1574), one of the first anatomists that, in 1552, drew very elegant figures published only 150 years later; he drew in his study "Tabulae Anatomicae", Table XLI, facial muscles, larynges introitus, thyroid gland, tongue and oral cavity, with excellent perspective and location of organs (Figure 1).

In that period, Thomas Wharton ${ }^{14,15}$ (16141673) described the submandibular duct, described in his 1656' "Adenographia" (first publishing), as a very important structure. His contribution consisted of, in a single paper, describing anatomy and function of salivary glands, arguing that... "the objective of the glands was to extract the necessary fluids from lymph and converge them to nerves" (Figure 2).

In that time, it is also important to highlight Marcello Malpighi' (1628-1694) that, contrary to Wharton, used pioneer microscopes (already invented by Zacharias Jansen and improved by Galileo Galilei and afterwards by Anton von Lewenhoek) and described in his studies "De Viscerum Structura" and "Opera Omnia" of 1665 and 1686, respectively, one of the first descriptions of salivary glands with a structured point of view, theorizing that "all our body is formed by little glandular structures".

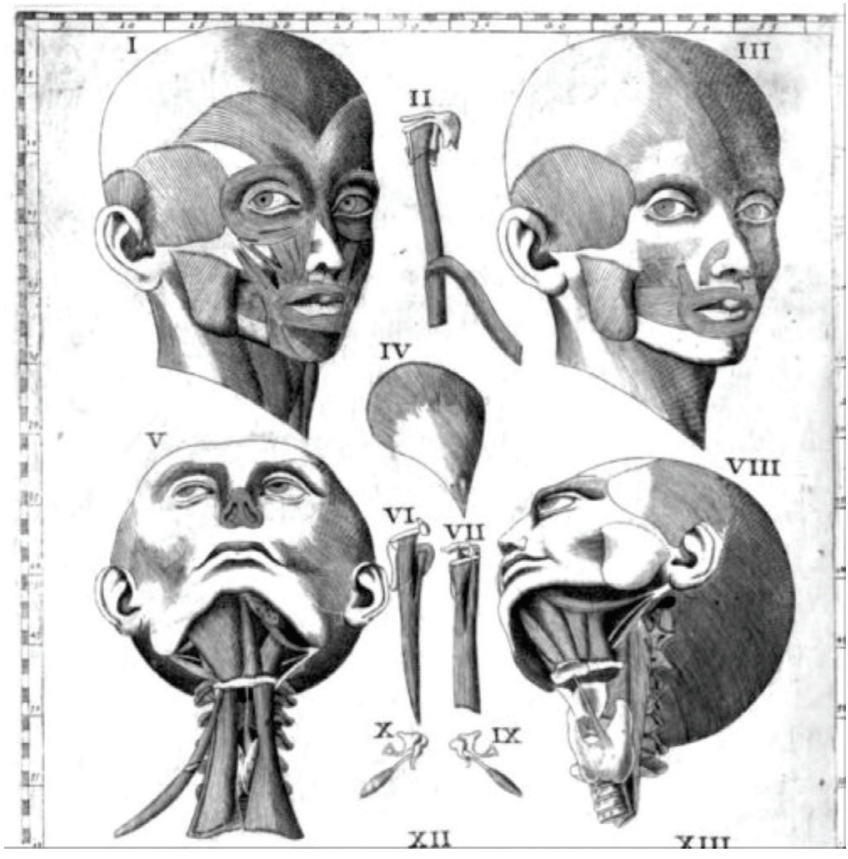

Figure 1. Tabulae Anatomicae. Tablet XLI showing the submandibular gland.
Niels Steenson or Nicolaus Stenonis (his latin name) (1638-1686) discovered in April 1660 the parotid duct, that was catheterized with a silver catheter in a dissected sheep head. When he demonstrated to his patron Gerard Blasé (16261682) his discovery, the patron tried to assume authorship, but he was unmasked by a presentation

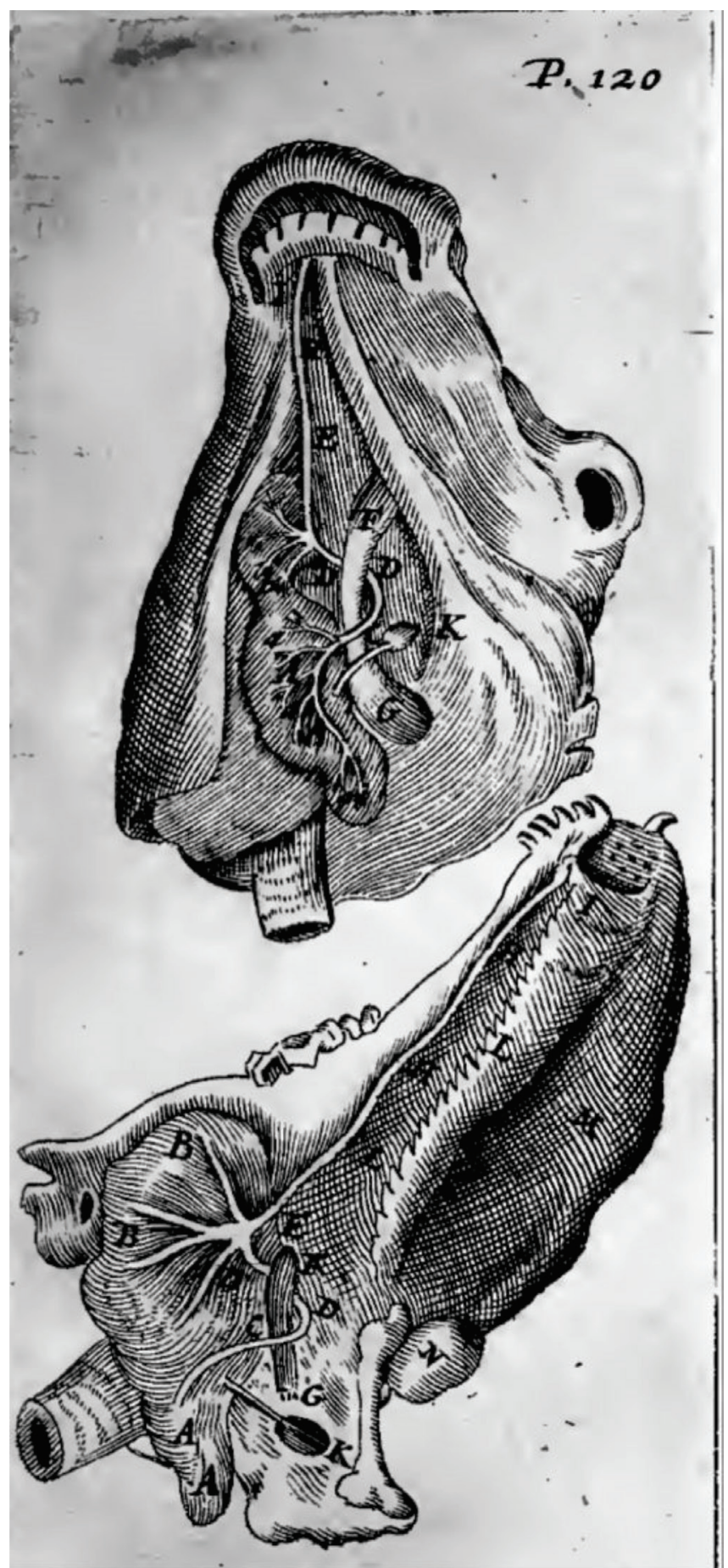

Figure 2. Thomas Wharton discovered the submandibular duct while dissecting a sheep head. 
performed again by Steenson in 1661 that showed the communication of parotid duct, lymphatic ducts of cervical lymph nodes, and submandibular glands, proving his discovery. He published his findings at "De Glandulis Oris et Novis Earundem Vasis" in $1661^{17}$.

Thomas Bartholin ${ }^{18}$ (1616-1680), professor of anatomy at Copenhagen University, and his son Caspar Bartholin (1655-1738), also a professor, named the sublingual duct (name that is used until nowadays), also quoted by other old authors, such as Antonii Nuck ${ }^{19}$ at his "Sialographia" in 1722.

Antonio Maria Valsalva20 (1666-1723), another valuable anatomist of his period, clearly described, in his book "De Aure Humana Tractatus in quo integra" the drawings of the lymph duct system and the Stensen duct, that permeate the parotid gland.

In 1685, Godefridi Bidlo21 (1649-1713), a poet, anatomy professor at Leiden University (Netherland), physician of the king of England and of William II from Orange, published his Atlas "Anatomia Humani Corporis" and detailed the tree nature of intraparotid ducts, with elegant refined draws for his time, showing an accurate technique, as observed in his $13^{\text {th }}$ Table.

Albercht von Haller ${ }^{22}$ published in 1727 his dissertation "Dissertatio Inauguralis Sistens Experimenta et Dubia Circa Ductum Salivalem Novum" recognizing the salivary ducts distribution and the sublingual gland ostium that debouches at the submandibular duct.

\section{Salivary Glands Surgery}

Before Renascence, interventions of the salivary glands were restricted to treat abscesses, ranulas and extraction of stones, when accessible. With corpse dissection from 1650 to 1750 , anatomic and functional knowledge were broadened and every surgeon contributed with techniques and treatments, that continuously evolved until today.

The name "Salivary Gland" was probably used by the first time by Andreas Vesalius in 1543; he described in his Chapter V of Book II the three types of "throat" glands: type I "paristhimia", that corresponds to the uvula, type II "antiades" or "acorn" (acorn in Latin), corresponding to the tonsils, and type III, with no specific name, corresponding to parotid and submandibular glands, that were also found in other animals, "that humidifies food, and must be regarded as important as other types". However, this anatomist did not describe any treatment for salivary gland diseases ${ }^{12}$.

However, in 1363, Guy de Chauliac ${ }^{23}$, a French surgeon, described surgical treatment of ranula to avoid death by asphyxia. In 1561, Pierre Franco described the treatment of parotid tumor in his $10^{\text {th }}$ book, Chapter CX, a reported by Nicaise ${ }^{24}$. In 1648, Jean Riolan (1580-1657) was the first to identify a rigid sick mass at the parotid gland, but not mentioned how to treat it.

In 1697, John Pechey ${ }^{25}$, an English physician, described in his book "A General Treatise of the Diseases of The Infants and Children" the treatment of ranula only when it grew and interfered in speech, "but could be done any given time".

German surgeon Lorenz Heister ${ }^{26}$ described the first parotidectomy in 1765, as well the treatment of ranula and stones at the floor of the mouth, and wrote in his book "A General System of Three Parts" Chapter XCVIII of First Volume: "Though we are furnished with various methods of removing feirrhous glands in most other parts of the body, yet I cannot meet with any direction for extirpation of the salival, maxillary, and parotid glands, which are frequently indurated and enlarged to a monstrous size...", stating that hemostasis should be careful due to carotid artery branches.

In 1781, JB Siebold, after removal of the parotid gland of a patient stated that "could easily differentiate digastric muscle and style-hiodeo muscle" and in 1796, Carl Alfred Gaspar von Siebold (1736-1807) stated that, when he operated a big parotid tumor, he noted that the place was deformed, assuming that he removed all gland, according to Velpeau ${ }^{27}$, in his book, Chapter I, article I of Title II: trunk surgeries.

John Hunter (1728-1793), a Scottish surgeon, in October 24th, 1785, resected a bulky 
parotid tumor without complications, as described in his "Case Books"28 (Figure 3).

In 1805, George McClellan, professor at Thomas Jefferson University, performed the first parotidectomy due to cancer in the USA. He operated more than 30 patients during that period, 11 been submitted to total resection of the gland with sacrifice of facial nerve. One patient died due to proximal ligature of common carotid artery, as described in his book "Principles and Practice of Surgery" of $1848^{29}$.

In cases of saliva fistula, in patients with War wounds, Deguise, in 1811, suggested the ligature of distal portion of the duct and, after transfixing it with a needle, fix it at the jugal mucosa to create a fistula directed to the oral cavity, and by this, he created the technique called by his name ${ }^{30}$.

For these wounds, in 1818, Morestin suggested the ligature of proximal stump of Stensen duct, to atrophy the gland, published in 1917 in his book, as related by Howard Baron ${ }^{31}$.

From the beginning of the 19th Century, it was initiate the suggestion to preserve facial nerve during parotid surgery, as shown by Granville Sharp Pattison' lecture in 1833. He opposed to the observation of Charles Bell about the impossibility to completely resect the gland ${ }^{32}$.

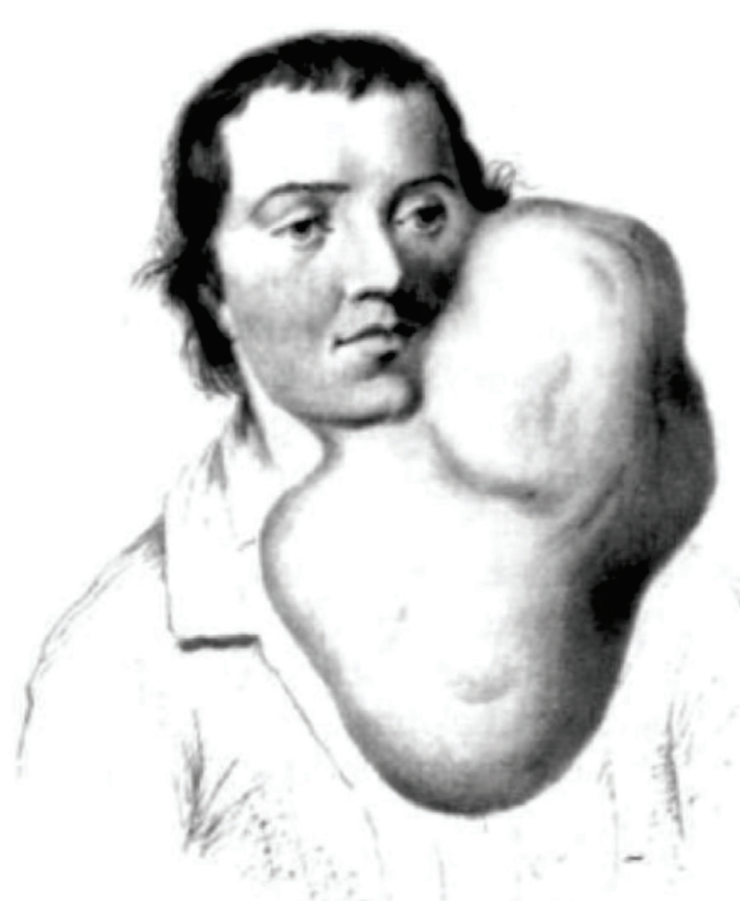

Figure 3. "Case Books" parotid tumor (John Hunter).
In 1823, an American surgeon from Baltimore, John Beale Davidge ${ }^{33}$, described the first total parotidectomy in a patient with "bell" parotid tumor, without anesthesia, with some anatomic references. However, he stated that it "was almost impossible the complete removal of the gland".

In 1825, Johann Ferdinand Heyfelder ${ }^{34}$, a German surgeon, professor at Erlangen, was the first to describe the preservation of the facial nerve branch during a parotidectomy, maintaining its function, an area where all others previous surgeons failed. After that, in January $24^{\text {th }}, 1847$, he described the first anesthesia in Germany, using sulfuric ether; he operated one hundred patients in his clinic, including two parotidectomies using that anesthesia.

In 1830, Bernhard Rudolf Konrad von Langebeck suggested, for the treatment of lesions of parotid duct, careful dissection and stump approximation for reanastomosis, when fistula was located anterior to the masseter, as described by John Fairbairn Binnie ${ }^{35}$, in his Atlas "Manual of Operative Surgery" of 1906.

In 1835, Alfred Velpeau published his well described series of cases, referring the location of facial nerve (he followed the superficial temporal artery and vein, cranial to caudal, until crossing the nerve branch, at the level of the neck of the mandibular condyle), in his book "New Elements of Operative Surgery" 27. He also described, along with Charles Bell, aside from the motor function of the facial nerve, the sensitive function of face by trigeminal nerve.

Anterior to that period, copious bleeding due to surgical technique caused "shock" (denomination given to the patient's condition), that many times was fatal, and was solved with manual compression, pneumatic compression or only dressings.

In 1844, Alexander E. Hosack ${ }^{36}$ described meticulously the removal of the parotid gland with ligature of extern carotid artery in a patient, and advocated that this ligature should be routinely performed for safe removal of the gland: "The operation of placing a ligature on the carotid artery is not very painful or dangerous in itself and if not successful in causing an atrophy of the tumor, it cannot in any way interfere with its removal afterwards by 
the knife". From then on, with the better knowledge of anatomy and refinement of surgical technique, bleeding was controlled by ligature of external carotid artery.

Surgery of the salivary glands were performed without anesthesia, that was only incorporated after the discovery (actually, rediscovery, since in 1490 Paracelsus von Hokeihein described paralysis of fishes, frogs and birds, without intention to use in men, and this information was lost for 350 years) of sulfur ether by William Thomas Green Morton in 1846 and by Crawford Williamson Long ${ }^{37}$

In 1846, surgeon John Collins Warren ${ }^{38}$ from Massachusetts-Boston Hospital, was the first to perform an oncologic surgery under general anesthesia with sulfur ether (administered by Morton) and described as a procedure to resect a mandible tumor of the patient Edward Gilbert Abbot, in a public demonstration in that Hospital ${ }^{39}$ (Figure 4).

In 1847, Charles Emmanuel Sédillot and Auguste Berard, both French surgeons, performed total parotidectomy without ligature of carotid artery, however, with paralysis of facial nerve, still without general anesthesia ${ }^{40}$

Facial nerve dissection during parotid surgery could now be performed with the patient under general anesthesia, with a better field due to bleeding control, and better anatomic evaluation of the nerve due to longer period of operatory time. Only then, near 1850, the thought of visualization of facial nerve started to grow.

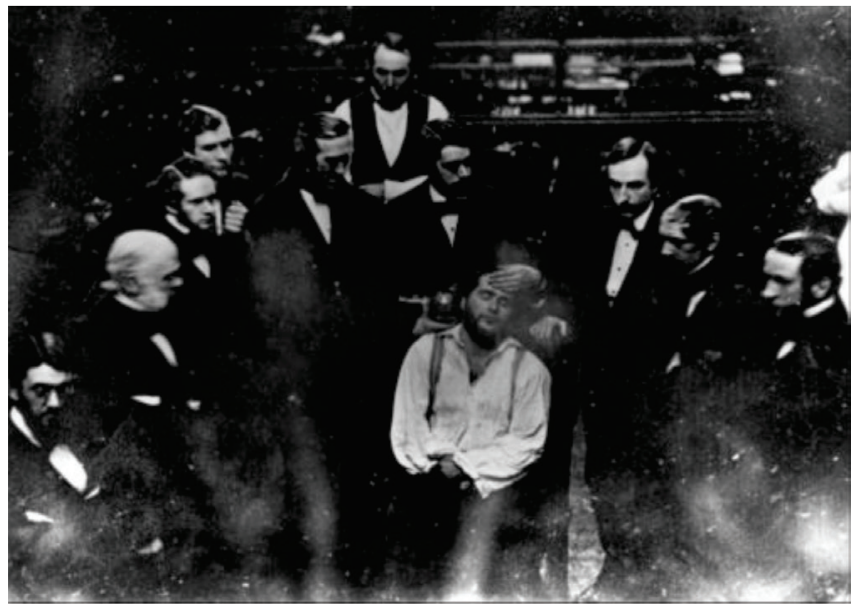

Figure 4. John Warren operates a jaw tumor in 1846.
So, in 1869, John Eric Erichsen ${ }^{41}$ stressed the importance of preservation of the "hard" portion of the facial nerve, performing dissection parallel to the tumor: "...injury to this nerve is best avoided by dissecting out the tumor by incisions parallel to its main trunk and chief branches, and especially by drawing the mass well forward, and directing the knife towards it..." as he describes in his book "The Science and Art of Surgery", in the chapter about Diseases of Parotid Gland, page 822

In 1892, Codreanu performed the first total parotidectomy with preservation of facial nerve, under general anesthesia, as described in his paper written in Romenian, quoted by Laage-Hellman ${ }^{42,43}$. The same can be said about Gaetano Parlavecchio, Italian surgeon, that in 1900 performed a parotidectomy under general anesthesia preserving the facial nerve to treat a parotid tumor, which he characterized as "sarcomatous".

In 1907, Thomas Carwardine ${ }^{44,45}$ (18971925), from Bristol Infirmary, in England, was the first to suggest previous identification of facial nerve before resection of parotid tumor, as he describes in his notes: "... by careful dissection and delicate material nerve was released and repaired with a catgut suture for ligature of anterior and posterior vessels" and observed that "... the expended care and time consumed would compensate by the esthetic result".

A new ere therefore began, in which it would be possible to preserve also the function of facial nerve during surgery for parotid gland tumors. Several techniques and ideas emerged, related to preservation of facial nerve and simultaneous removal of the tumor with curative intent.

\section{History of Localization Techniques of Facial Nerve}

In literature, there is still debate about who was the first surgeon to perform successful parotidectomy preserving facial nerve, and two names are always featured: Codreanu and Carwadine. We should stress the possibility of preservation only occurred due to anesthesia, when the surgeon did not have to operate rapidly to avoid "shock" due to 
pain and hypovolemia, since the operated patients had bulky neoplasms.

In that time, it was figured that facial disfigurement after section of nerve during surgery was very harmful for the patient and also for the reputation of the surgeon, making necessary the search for new techniques to easy the surgery without this feared complication.

Therefore, the techniques for localization of the facial nerve advanced from that time on. The knowledge of anatomy of previous era allowed the proposal of new surgical techniques to protect initially and consequently preserve the facial nerve.

We can also quote, aside from Carwadine and Codreanu, in 1907, Leveson Gower Gunn ${ }^{46}$, a surgeon from Dublin, that described his experience in a 45 years old patient with parotid tumor, without describing the technique, but affirming that "... yet I think that we are justified in promising a patient that complete removal of the parotid gland can be done and a fair amount of facial movement will remain after such an operation".

In 1913, Vilray Papin Blair ${ }^{47}$, a surgeon from the University of Washington, right after Carwardine, stated in his book: "Surgery and Diseases of the Mouth and Jaws", that facial nerve dissection should be done previously to resection of parotid tumor, localizing the nerve at the superior portion of the posterior venter of digastric muscle, as it is demonstrated in this phrase "...With very large tumors, to which the relation of the seventh nerve is not known, it may be advisable to locate the trunk of the nerve, as it emerges from under the upper part of the anterior belly of the digastric muscle, and to follow it and its main branches until their relation to the tumor is evident".

In 1921, Walter Ellis Sistrunk ${ }^{48}$ adviced to localize facial nerve trunk by retrograde via, by identification of what he called infra-mandibular division of facial nerve close to the jaw angle and superficially to facial vessels, following the nerve proximally at the gland until the point of division of the main branch. However, as other authors quoted, there was a high rate of facial nerve paralysis by this technique.
In 1923, two other authors, Alfred W. Adson ${ }^{49}$ and Willian O. Ott, described their technique for localization of facial nerve trunk retrogradely, similar to Sistrunk technique, with one more incision anterior to tragus to localize the temporal branch and then dissecting it caudally, as Sistrunk. Next, they dissected the infra-mandibular branch cranially to join both parts and finally, next to the dissected temporal branch, elevate the superficial parotid tissue (Figure 5).

In 1941, Hamilton Bailey50,51 described that the localization techniques of the facial nerve trunk retrogradely increased very much the risk of facial paralysis, since were too laborious and time consuming, with too much manipulation of the nerve and branches. So, he proposed releasing the gland capsule and initially localize the facial nerve trunk and the "pes anserinus", and waiting the intra-operatory period to decide and choose which technique should be used. He was the first to agree with LJ McCormack ${ }^{52}$ and write in his article of 1947 the concept of dividing the parotid gland in a deep and superficial lobes

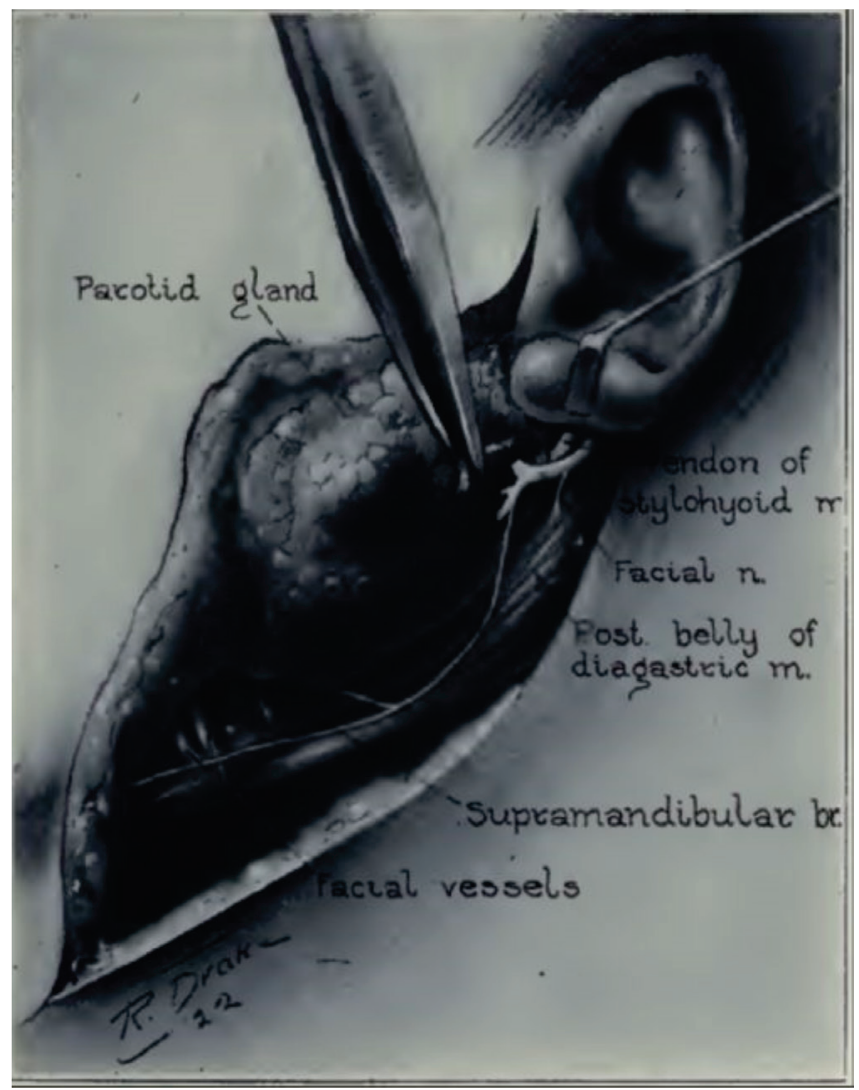

Figure 5. Technique for localization of facial nerve: retrograde localization by Alfred W. Adson. 
separated by the facial nerve, allowing improvement of the knowledge of surgical anatomy of the gland.

In 1951, Henry Samuel Shucksmith ${ }^{53}$ described the resection of superficial parotid initially exposing the main branch of facial nerve, that was localized right after its emergence by the stylemastoideo foramen and, from there on, perform dissection of its nervous branches. This was one of the main techniques used at that time and that is still used nowadays.

In 1952, Hayes Martin ${ }^{54}$ wrote that the exposition of the facial nerve trunk should be routinely performed initially, before resecting the parotid gland tumor, considering this the best method for avoidance of nerve damage (Figure 6).

With these two authors, it was started the era of antegrade dissection of facial nerve, or more specifically, localization of main branch with posterior dissection of its branches, that is used until today.

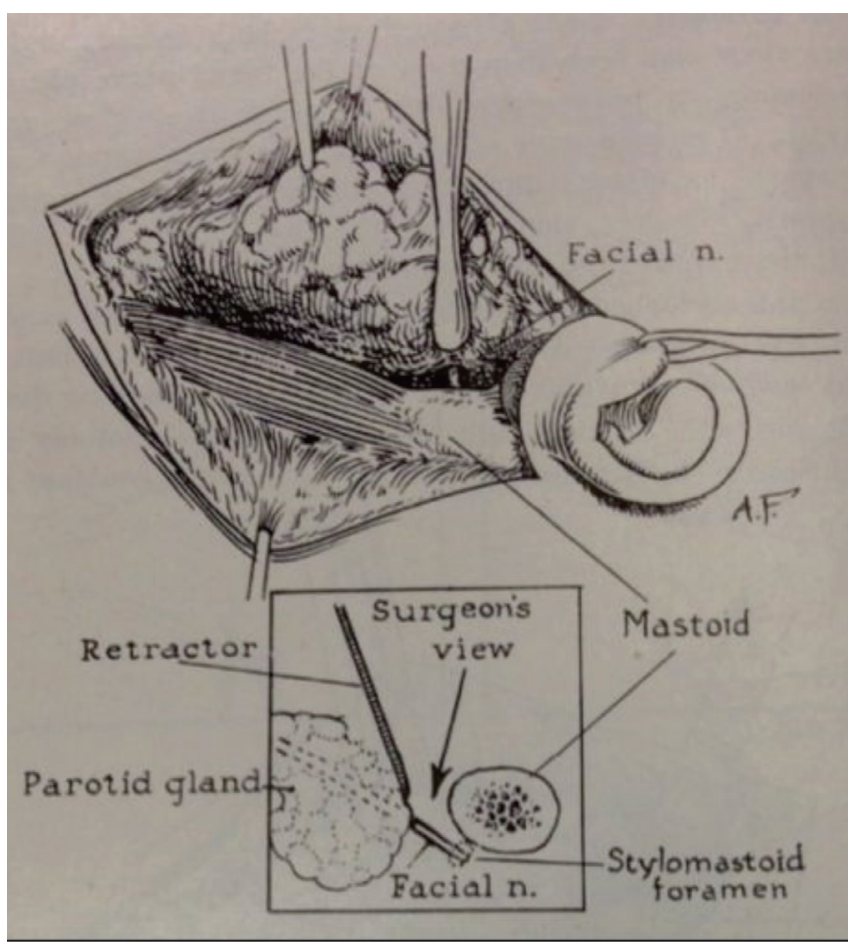

Figure 6. Hayes Martin technique: exposition of the facial nerve trunk.

\title{
R E S U M O
}

\begin{abstract}
As neoplasias das glândulas salivares são relativamente raras, compreendendo cerca de $1 \%$ das neoplasias de todo corpo, com incidência de 1/100.000 habitantes por ano. As neoplasias benignas predominam sobre as malignas. O prognóstico depende muito do tipo histológico, grau de diferenciação, localização, infiltração de tecidos vizinhos e da presença de metástases regionais ou a distância. 0 principal tratamento ainda é a cirurgia, com os seus desafios e dificuldades, devido aos ramos do nervo facial nas glândulas salivares maiores, seguido de radioterapia e em casos selecionados quimioterapia adjuvante. O objetivo desta revisão é fornecer ao leitor uma abordagem histórica sobre o tratamento das doenças das glândulas salivares, com especial atenção às doenças da glândula parótida assim como peculiaridades associadas aqueles que as estudaram ao longo da história.
\end{abstract}

Descritores: Cirurgia Geral. Glândula Parótida. Neoplasias Parotídeas. História da Medicina

\section{REFERENCES}

1. Thompson RC. Assyrian medical texts. Proc R Soc Med. 1924;17(Sect Hist Med):1-34.

2. Ghalioungui P. The House Of Life Per Ankh: magic and medical science in ancient Egypt. B. M. Israel: Amsterdam; 1963.

3. Adams F. The genuine work of Hippocrates. Translated from the Greek with a preliminary discourse and annotations. Sydenham Society: London; 1849.

4. Ninnin M. Traduction des Ouvrages d'AureliusCornelius Celse, sur la Médecine. Desaint \& Saillant: Paris; 1753.

5. Adams F. The seven books of Paulus Aegineta. London: Sydenham Society: London; 1843.
6. Coxe JR. The writings of Hippocrates and Galen. Lindsay and Blakiston: Philadelphia; 1846.

7. Tabatabaei SM, Kalantar-Hormozi A, Asadi M. Razi's description and treatment of facial paralysis. Arch Iran Med. 2011;14(1):73-5.

8. Azizi $\mathrm{MH}$. The otorhinolaryngologic concepts as viewed by Rhazes and Avicenna. Arch Iran Med. 2007;10(4):552-5.

9. Kaadan AN, Dababo MH. Ranula in the Arab Medical Heritage. JISHIM. 2006;5(1):57-9.

10. Malgaigne JF. Oeuvres complétes d'Ambroise Paré. JB Billiere: Paris;1840.

11. Unschuld PU. Huang Di nei jing Su Wen. Nature, knowledge, imagery in an ancient Chinese medical text. University of California Press: California; 2003. 
12. Vesalius A. De humani corporis fabrica libre septem. Basileae: Ex officina Ioannis Oporini; 1543.

13. Eustachii B. Tabulae anatomicae clarissimi viri. Roma: Francisci Gonzagae; 1714.

14. Cook HJ. Thomas Wharton's Adenographia, first published in London in 1656. Med Hist. 1998;42(3):411-2.

15. Wharton T. Adenographia. Amsterdam: Joannis Ravesteinii; 1659.

16. Malpighi M. Opera Omnia. Londini: Prostant apud Robertum Scott; 1686.

17. Stenonis N. Disputatio Anatomica De glandulis oris, et nuper observatis inde prodeuntibus vasis prima. Lugduni Batavorum: Apud Johannem Elsevirium; 1661.

18. Bartholin T. Anatomia Reformata. Hage-Comitis: Adriani Veac; 1655.

19. Nuck A. Sialographia \& Ductuum Aquoforum anatome Nova. Lugduni Batavorum: Jordanum Luchtmans; 1722.

20. Valsalva AM. De Aure Humana Tractatus. Lugduni Batavorum: Gisbertum Langerk, Johannem Hasebroek; 1735.

21. 21.Bidlo G. Anatomia Humani Corporis. Amsterdam: Joannis a Someren, Haeredum Joannis a Dyk,Henrici\&Viduae Theodori Boom; 1685.

22. Wittivh J, Haller A. Dissertatio Inauguralis Sistens Experimenta et Dubia Circa Ductum Salivalem Novum Coschwizianum. Helveto Bernas: Jakob Wittich; 1727.

23. Nicaise E. La Grande Chirurgie de Guy Chauliac, composee en I'an 1363. Paris: Ancienne Libraire Germier Bailliere et Cie; 1890.

24. Nicaise E. Chirurgie de Pierre Franco de Turries en Provence composee en 1561. Paris: Ancienne Libraire Gerner Bailliere et Cie; 1895.

25. Pechey J. A general treatise of the diseases of the infants and children. London: R Weelington; 1697.

26. Heister L. A general system of surgery in three parts. London: W. Innys, C Davis; 1750.

27. Velpeau ALM. New elements of operative surgery with an atlas of nearly three hundred engravings. Washington: Duff Green; 1835.
28. Kirkup J. John Hunter's surgical instruments and operative procedures. Vesalius. 1995;1(1):22-6.

29. McClellan G. Principles and practice of surgery. Philadelphia: Elliot Grigg; 1848.

30. Keen WW, editor. Surgery: its principles and practice. Philadelphia: WB Saunders; 1916.

31. Baron HC. Surgical correction of salivary fistula. Ann Surg. 1961;153:545-54.

32. Pattison GS. Lecture delivered in Jefferson Medical College. Has the parotid gland ever been extirpated. Philadelphia: Jefferson Medical College; 1833.

33. Davidge JB. Case of extirpation of the entire parotid gland. Baltimore Philosophical J Rev. 1823;1(1):165-83.

34. Heyfelder JF. Die versuche mit dem schwefeläther. Erlangen: Verlag von Carl Heyder; 1847.

35. Binnie JF. Manual of operative surgery. Philadelphia: P Blakistons Son; 1906.

36. Hosack AE. Extirpation of a tumor of the parotid; with observation upon the pathology of that gland. N Y J Med. 1844; March.

37. Reis Junior A. O primeiro a utilizar anestesia em cirurgia não foi um dentista. Foi o médico Crawford Williamson Long. Rev Bras Anestesiol. 2006;56(3):304-24.

38. Warren E. The Life of John Collins Warren, M.D. Boston: Ticknor and Fields; 1860.

39. Moore FD. John Collins Warren and his act of conscience: a brief narrative of the trial and triumph of a great surgeon. Ann Surg. 1999;229(2):187-96.

40. Billings JS. The history and literature of surgery. In: Dennis FS, editor. System of surgery. Philadelphia: Lea Brothers; 1895. p.17-144.

41. Erichsen JE. The science and art of surgery. Philadelphia: Collins Printer; 1869.

42. Laage-Hellman JE. Facial nerve in parotidectomies. Arch Otolaryngol. 1965;81(5):527-33.

43. Codreanu M. Tumora in regiunea parotidei in dreapta: operat recidivat peste cinci ani: operat a dona oara: vindicarea cu conservarea facialului siaglandei parotide. Spitalul Bucurest. 1892;12:273.

44. Kidd HA. Complete excision of the parotid gland with preservation of the facial nerve. $\mathrm{Br}$ Med J. 1950;1(4660):898-91. 
45. Carwardine T. Excision of the parotid gland with preservation of the facial nerve: its possibility. Lancet. 1907;170(4387):892-7.

46. Gunn LG. Excision of the parotid gland with preservation of the facial nerve. Lancet. 1907;170(4388):984.

47. Blair VP. Surgery and diseases of the mouth and jaws. 2nd ed. St Louis: CV Mosby Company; 1913.

48. Sistrunk WE. Tumor of the parotid gland. Surg Clin North Am. 1921;1:1515-21.

49. Adson AW, Ott WO. Preservation of the facial nerve in the radical treatment of parotid tumours. Arch Surg. 1923;6(3):739-46.

50. Bailey $\mathrm{H}$. The treatment of tumours of the parotid gland with special reference to total parotidectomy. Br J Surg. 1941;28(11):337-46.

51. Bailey H. Parotidectomy: indications and results. Br Med J. 1947;1(4499):404-7.
52. McCormack LJ Cauldwell EW, Anson BJ. The surgical anatomy of the facial nerve with special reference to the parotid gland. Surg Gynaecol Obst. 1945;80:620.

53. Shucksmith HS, Boyle TM, Walls WK. The surgery of parotid tumours; exposure of main trunk of facial nerve. Br Med J. 1951;2(4735):830-1.

54. Martin $\mathrm{H}$. The operative removal of tumors of the parotid salivary gland. Surgery. 1952;31(5):670-82.

Received in: 19/10/2016

Accepted for publication: 09/12/2016

Conflict of interest: none.

Source of funding: CAPES-MEC-BRAZIL.

\section{Mailing address:}

Giulianno Molina Melo

E-mail: giuliannomolina@gmail.com giulianno_molina@hotmail.com 